\title{
Microstructural Characterization of the Garcinia mangostana Fruit at Different Maturity Level
}

\author{
Marisca Evalina Gondokesumo ${ }^{1 *}$, Bambang Pardjianto ${ }^{2}$, Sutiman Bambang Sumitro ${ }^{3}$, \\ Wahyu Widowati ${ }^{4}$ and Arbi Dimyati ${ }^{5}$ \\ ${ }^{1}$ Faculty of Medicine, Brawijaya University, Malang, Indonesia; mariscaevalina@gmail.com \\ 2Department of Plastic Surgery, Saiful Anwar General Hospital, Faculty of Medicine, \\ Brawijaya University, Malang, Indonesia \\ ${ }^{3}$ Department of Biology, Faculty of Sciences, Brawijaya University, Malang, Indonesia \\ ${ }^{4}$ Faculty of Medicine, Maranatha Christian University, Bandung, Indonesia \\ ${ }^{5}$ Center for Science and Technology of Advanced Materials, PSTBM-BATAN, Indonesia
}

\section{Abstract}

Mangosteen (Garcinia mangostana L.) is one of the most popular fruits which has been widely used medicinally. The major constituents are mostly found in the pericarp particularly, xanthones, which are tricyclic isoprenylated polyphenols. Xanthones have been reported for its anti-oxidant, anti-inflammatory, anti-bacterial, anti-proliferative, proapoptotic and anti-carcinogenic activities. In this study, the mangosteen pericarps in various maturity levels were investigated using various characterization techniques such as PSA (Particle Size Analyzer), Scanning Electron Microscope (SEM), $X$-ray Diffraction (XRD), and X-ray Fluorescence (XRF). The results revealed the characteristic of mangosteen at various maturity levels.

Keywords: Mangosteen, Particle Size, SEM, Xanthone, X-ray Diffraction, XRD

\section{Introduction}

Plants and their fruits have been used since ancient time as supplement and medicine to treat diseases. Approximately two-third of world population uses plant based products as their main medicine ${ }^{1}$. Garcinia mangostana L. (Clusiaceae), commonly known as mangosteen, have been used as a traditional medicine in Southeastern Asia for the treatment of diarrhea, dysentery, inflammation, ulcers and wound healing ${ }^{2,3}$. Mangosteen is cultivated mainly in Indonesia, Malaysia, Philipina and Thailand ${ }^{4-6}$. Medicinal properties of $G$. mangostana are associated with its bioactive compounds, xanthone. Xanthone is a tricyclic isoprenylated polyphenol. Previous investigation shows that xanthone are antioxidant ${ }^{5,7}$, anti-bacterial, antiproliferative, proapoptotic, anti-carcinogen ${ }^{8-10}$ and anti-inflammatory properties ${ }^{11}$.

Xanthone can be found in every part of mangosteen, mainly in fruit pericarp. Mangosteen contains 17\% of pericarp ${ }^{12}$, which contains $62.05 \%$ of water, $0.63 \%$ of fat, $0.71 \%$ of protein, $1.17 \%$ of total sugar and $35.61 \%$ of carbohydrate ${ }^{13}$. Xanthone content of mangosteen pericarp is about 108 to $124 \mathrm{mg}$ per $100 \mathrm{~g}^{14,15}$. The ripeness level significantly affects the xanthone content of mangosteen ${ }^{16}$. In this study, we investigated the physical and chemical properties of mangosteen pericarps depending on the maturity level ${ }^{17}$ (Table 1), using various characterization techniques such as PSA (Particle Size Analyzer), Scanning Electron Microscope (SEM), X-ray Diffraction (XRD), 
and X-ray Fluorescence (XRF). The study aims to get insight into the microstructure of mangosteen pericarp in accordance to their maturity level and xanthone content. Furthermore, it can give insight to maximize the yield of xanthones.

Table 1. Maturity level classification of mangosteen

\begin{tabular}{|c|c|}
\hline Maturity Level & Properties \\
\hline Level 1 & $\begin{array}{l}\text { Green yellowish, high mucus content. The } \\
\text { inner part of fruit cannot be separated } \\
\text { from the flesh. }\end{array}$ \\
\hline Level 2 & $\begin{array}{l}\text { Yellow reddish with distribution of red } \\
\text { colored fleck. Lower mucus content. } \\
\text { The inner part of the fruit still cannot be } \\
\text { separated from flesh. }\end{array}$ \\
\hline Level 3 & $\begin{array}{l}\text { Red brownish. Mucus still exists. The inner } \\
\text { part of fruit can be separated from the } \\
\text { flesh. }\end{array}$ \\
\hline
\end{tabular}

The color becomes red purple. The mucus
is lesser. The inner part of fruit can be
separated from the flesh and the fruit can
be consumed.

Purple reddish. Fruit starts to ripe. The
mucus disappears, and the fruit can be
easily separated.

\section{Methods}

\subsection{Extraction}

The extraction of mangosteen pericarp was performed following maceration method. Mangosteen pericarp was obtained from Bandung, West Java. Mangosteen was air drieduntilthewatercontent wasabout $5 \%$ priortocrushing in an electrical blender. Briefly $700 \mathrm{~g}$ of mangosteen pericarp mass was macerated using $96 \%$ ethanol (1:5) for 5 days and stirred every 3 hours. The filtrate was dried using evaporator and freeze dried to obtain the powder. The powder was stored in desiccators until used.

\subsection{Characterization}

The mangosteen extract in various maturity levels were subjected to microstructure characterization using PSA, SEM, XRD and XRF. For SEM analysis, the mangosteen extract was poured homogenously onto the carbon double tip on the SEM sample holder stub. For the elemental composition in SEM, an energy dispersive X-ray (EDX) detector attached on SEM (SEM JEOL JSEM2650LV) was used. For XRD analysis Imperian with $\mathrm{Cu}$ source was used. The XRD results were analyzed using Ritveld Refinement to derive information about the phase and crystals may occur.

\section{Results}

PSA measurement of the mangosteen extract in various maturity levels is presented in Figure 1 and Table 2. Particle of mangosteen powder at level 5 exhibited the smallest size, whereas those at level 3 exhibited the highest size.

Table 2. Particle size of mangosteen pericarp extract as measured by PSA

\begin{tabular}{cc}
\hline Mangosteen level & Size $(\mathrm{nm})$ \\
\hline 1 & $81.8 \pm 21.1$ \\
2 & $72.6 \pm 20.4$ \\
3 & $1244.1 \pm 341.0$ \\
4 & $1112.2 \pm 256.5$ \\
5 & $57.0 \pm 14.5$ \\
6 & $199.2 \pm 58.9$ \\
\hline
\end{tabular}

Data are presented in Mean \pm Standard Deviation

Figure 2 shows the SEM image of the microstructure of mangosteen pericarp extract at the maturity levels 1-6 which generally showed granular and plate like structure composing of large coagulates. Sample of maturity levels 3 and 6 have shown clearly smaller powder grains than those of the sample of maturity levels 1, 2, 4 and 5. It was distinguished by the contrast deficiency by the sample with fine grain size. It is almost impossible to measure single grain on the sample 1, 2, 4 and 5 because the sample forms large block of particle agglomerations. 


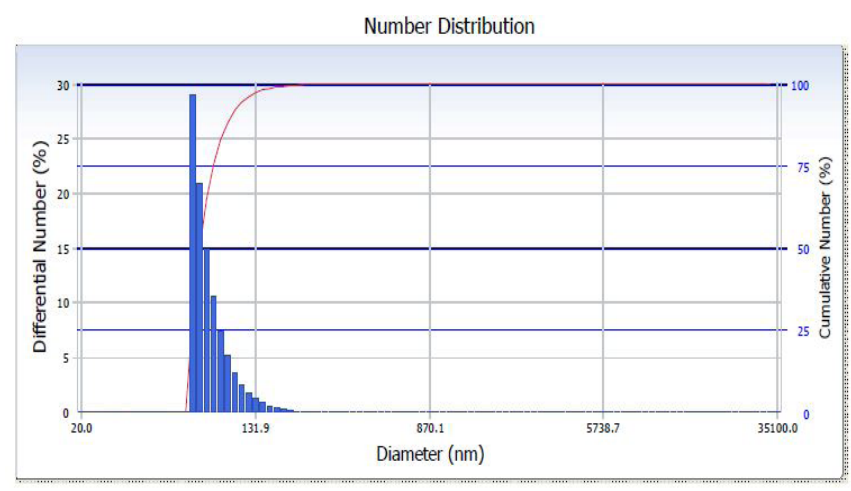

a

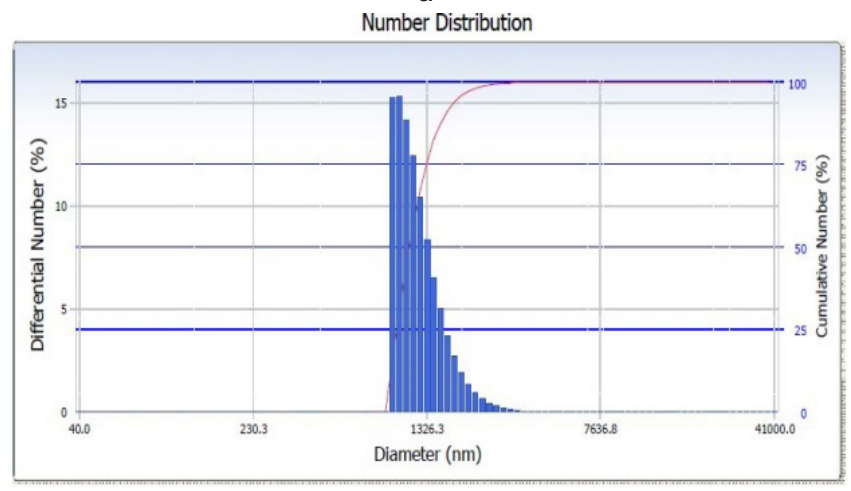

C

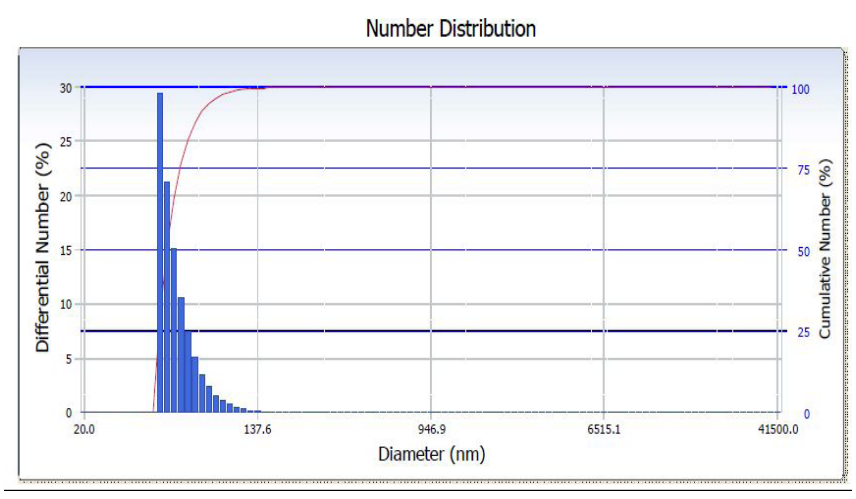

e

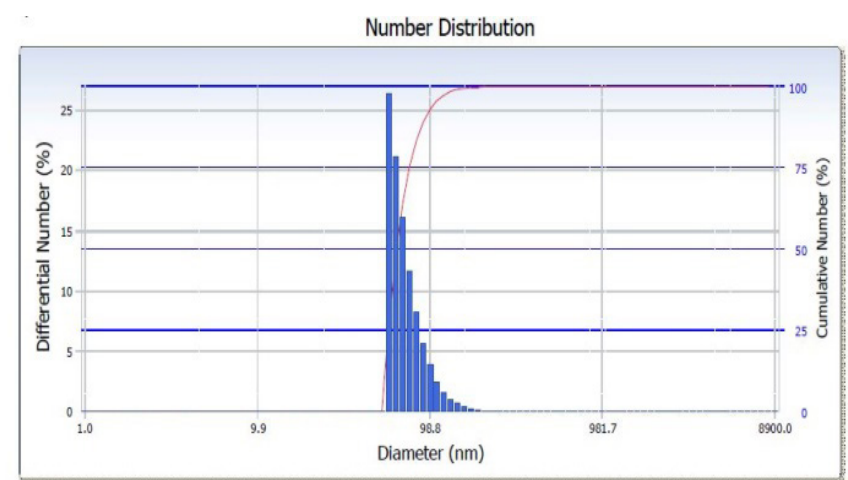

b

Number Distribution

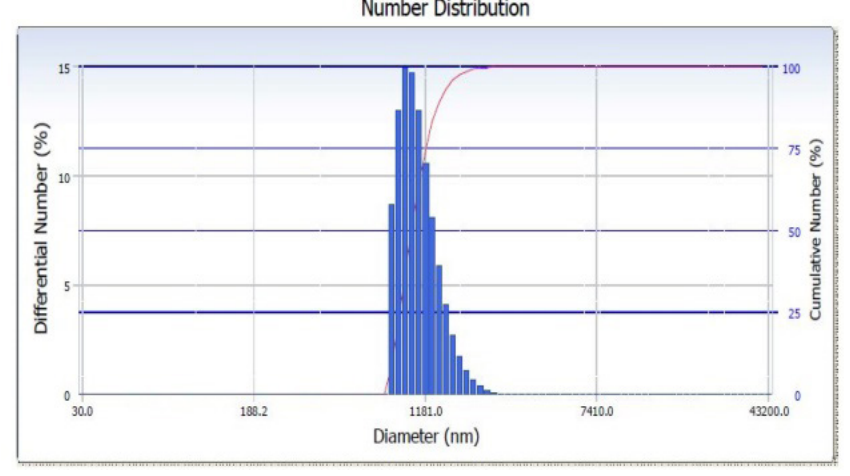

d

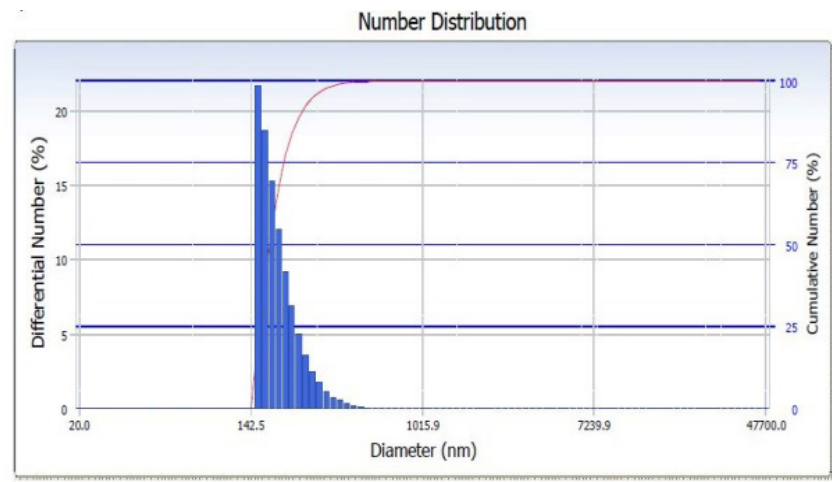

f

Figure 1. Particle size distribution of Mangosteen pericarp; a. level 1; b. level 2 c. level 3; d. level 4; e. level 5; f. level 6.

a

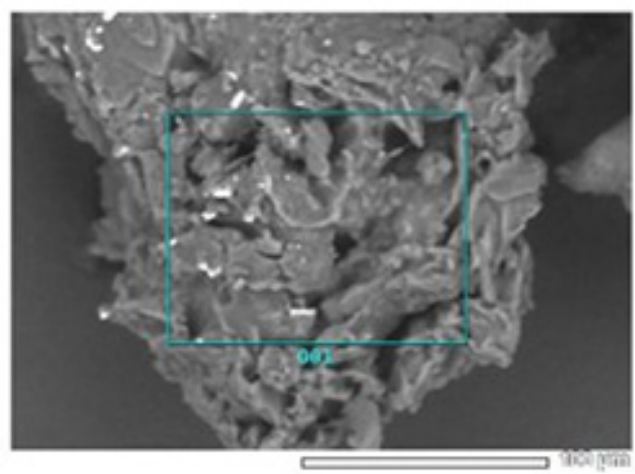

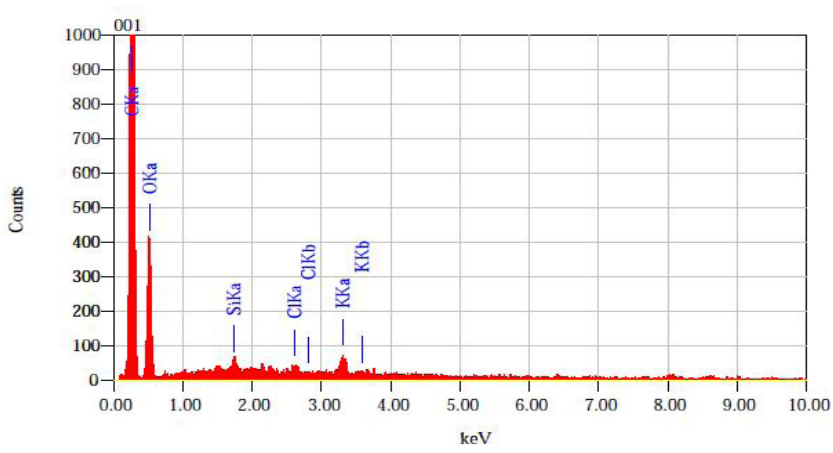


b
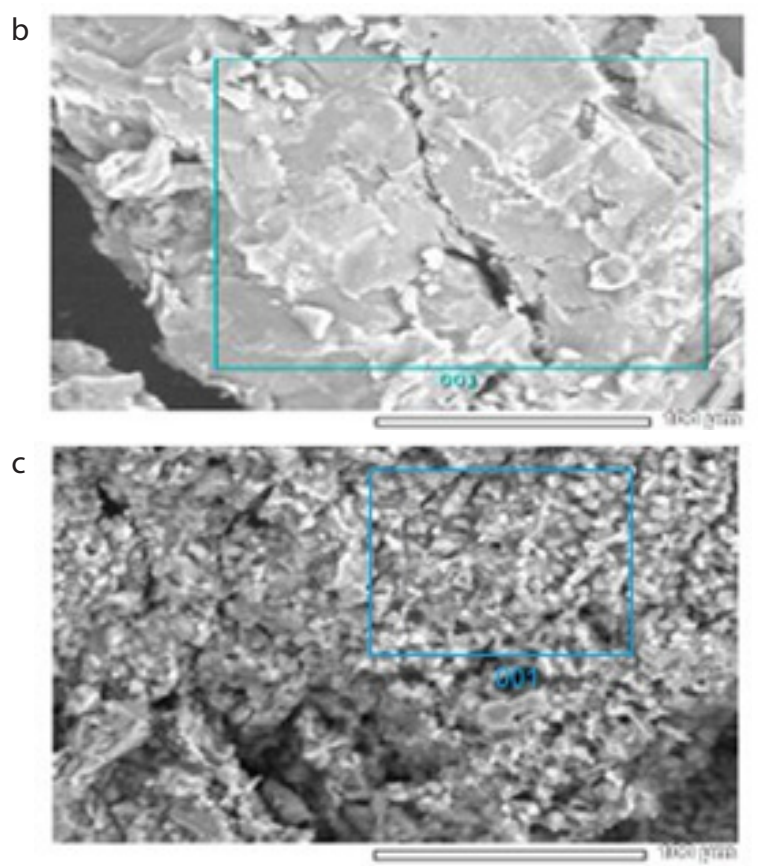

d

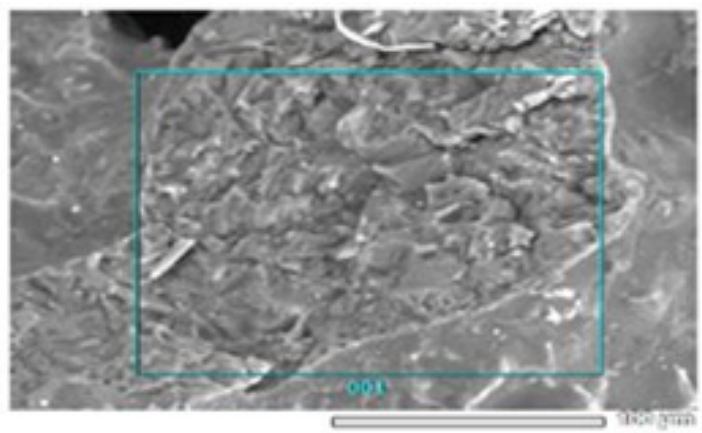

e

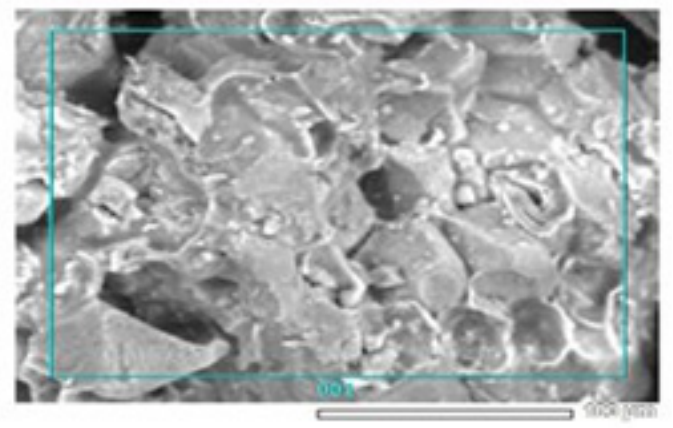

$f$

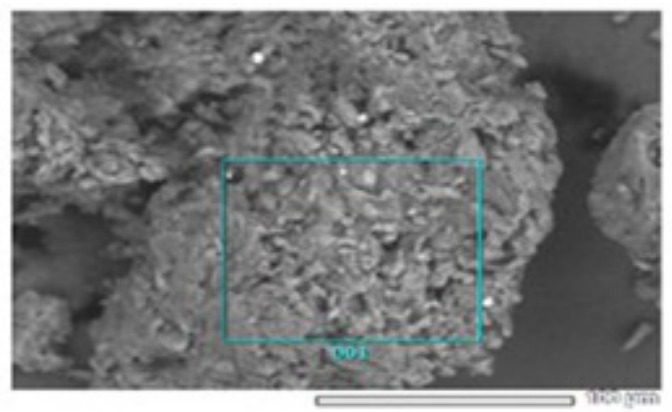

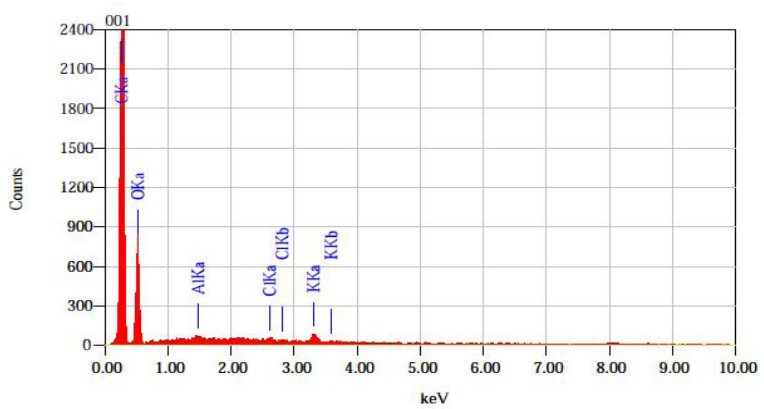
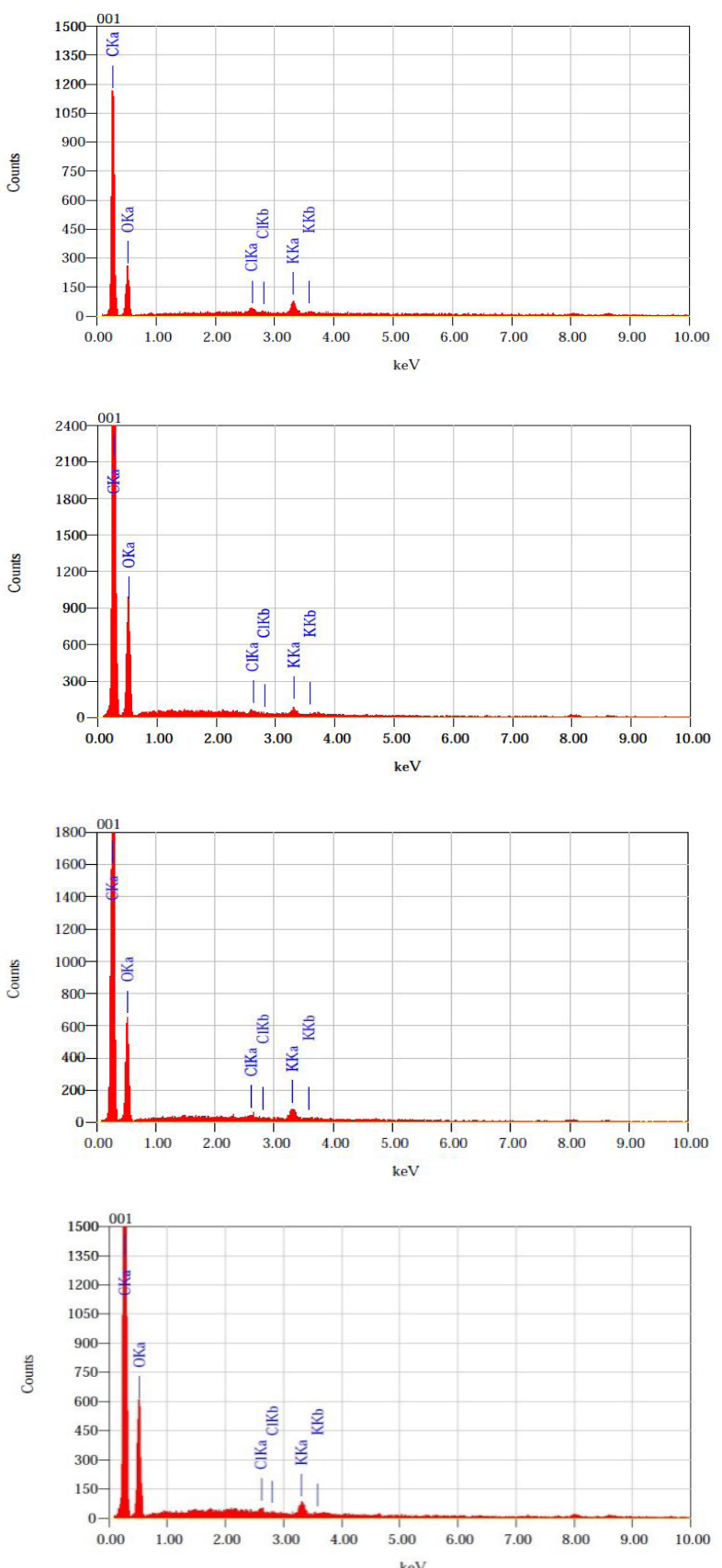

Figure 2. SEM SE images of mangosteen pericarp samples at maturity level and their corresponding EDX spectrum, a. level 1; b. level 2 c. level 3; d. level 4; e. level 5; f. level 6. 
The corresponding EDX spectrums are also represented in Figure 2 on the right side revealing the elemental composition of the samples. Mainly the samples contain $\mathrm{C}, \mathrm{O}, \mathrm{Cl}$ and $\mathrm{K}$. The mangosteen pericarp level 1 revealed the elemental content $\mathrm{C}, \mathrm{O}, \mathrm{Cl}, \mathrm{K}$ and $\mathrm{Si}$ about $64.20 \%$, $34,52 \%, 0.22 \%, 0,72 \%$ and $0,33 \%$ respectively. Mangosteen peri-carp level 2 was crystalline in nature containing $\mathrm{Al}$ $0.1 \%$, whilst $\mathrm{Si}$ was not detected. Level of $\mathrm{C}, \mathrm{O}, \mathrm{Cl}$ and $\mathrm{K}$ about $65.32 \%, 33.96 \%, 0.17 \%$ and $0.45 \%$ respectively. Mangosteen pericarp level 3 showed globular form, softer than mangosteen pericarp level 1 and 2 which was about 5 $\mu \mathrm{m}$, as shown in EDX results. Level of $\mathrm{C}, \mathrm{O}, \mathrm{Cl}$ and $\mathrm{K}$ about

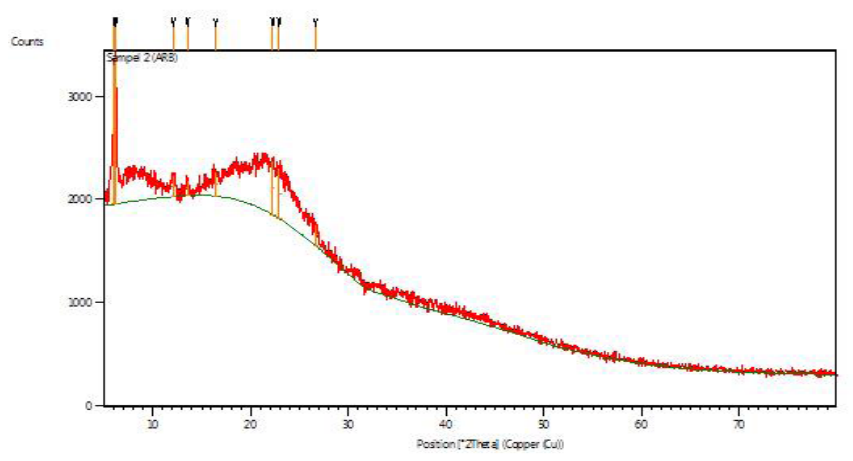

a

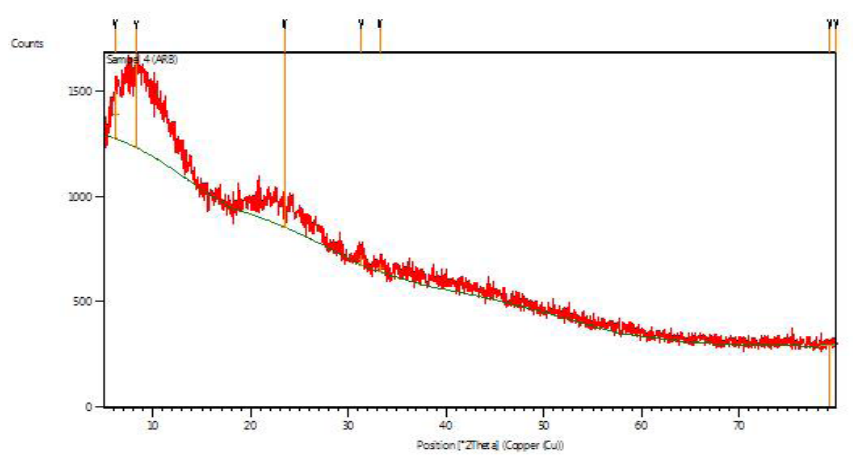

C

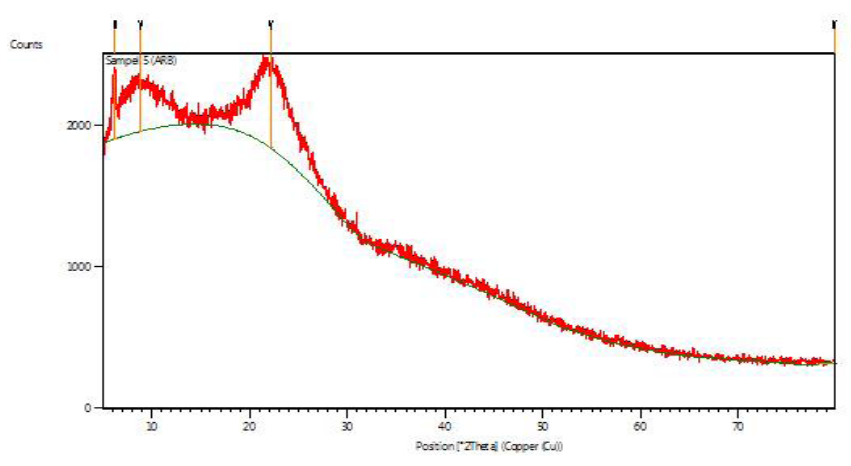

e
$61.38 \%, 36.49 \%, 0.48 \%$ and $1.65 \%$ respectively. Mangosteen pericarp level 4 has granule size of $20 \mu \mathrm{m}$, crystalline and its level of C, O, Cl and $\mathrm{K}$ was $65.42 \%, 34.20 \%, 0.10 \%$ and $0.28 \%$. Mangosteen pericarp level 5 showed granules form and also combined form. Its granule were between 5-50 um, crystalline and mainly composed by $\mathrm{C}, \mathrm{O}, \mathrm{Cl}$ and $\mathrm{K}$ with $61,18 \%, 37,94 \% ; 0,19 \%$ and $0,69 \%$ respectively. Mangosteen peri-carp level 6 showed granules form and also combined form. Granule was $10 \mu \mathrm{m}$, crystalline. Main components of Mangosteen pericarp level 6 were $\mathrm{C}, \mathrm{O}, \mathrm{Cl}$, and $\mathrm{K}$ with $62,41 \%, 36,67 \% ; 0,23 \%$ and $0,68 \%$. respectively.

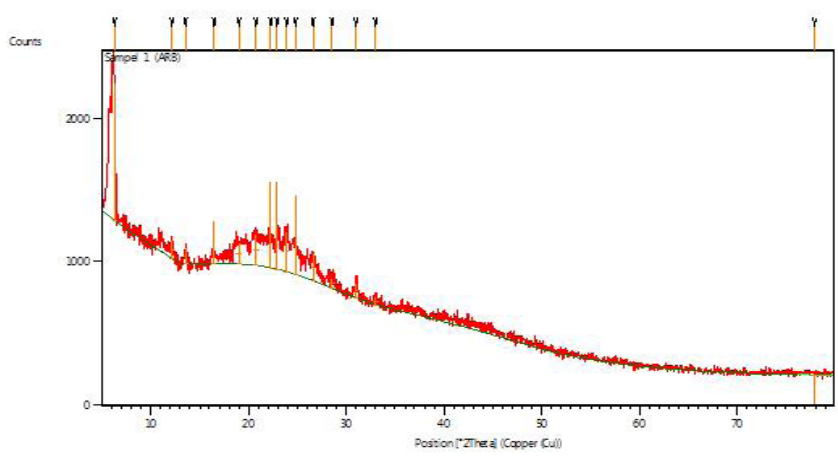

b

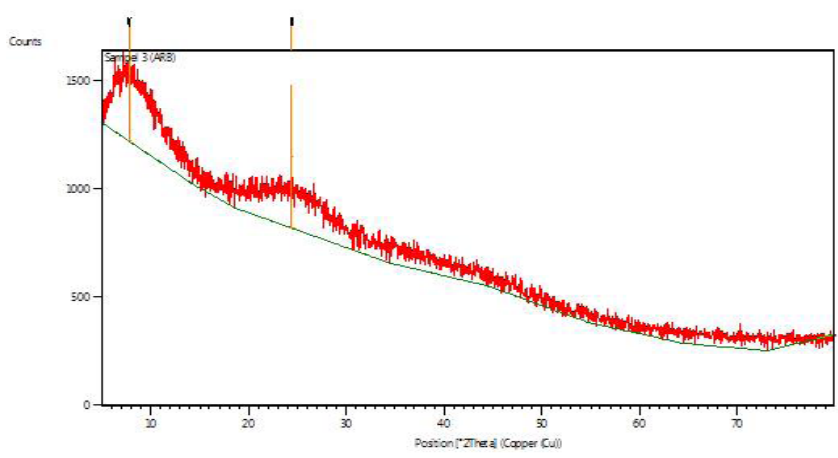

d

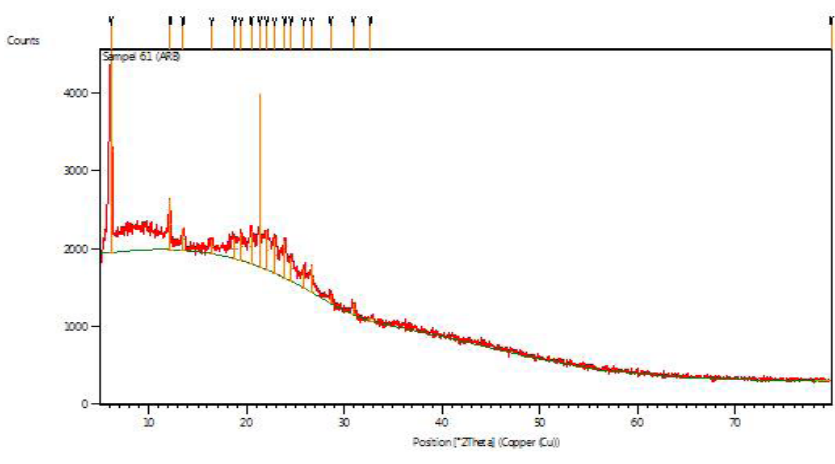

f

Figure 3. XRD analysis of mangosteen pericarp extract, a. Mangosteen pericarp level 1; b. Mangosteen pericarp level 2; c. Mangosteen pericarp level 3; d. Mangosteen pericarp level 4; e. Mangosteen pericarp level 5; f. Mangosteen pericarp level 6. 
Table 3. Elemental concentration of mangosteen pericarp extract analyzed with X-ray fluorescence (\%)

\begin{tabular}{lcccccc}
\hline \multirow{2}{*}{ Elements } & \multicolumn{7}{c}{ Concentrations mangosteen pericarp level (\%) } \\
\cline { 2 - 7 } & $\mathbf{1}$ & $\mathbf{2}$ & $\mathbf{3}$ & $\mathbf{4}$ & $\mathbf{5}$ & $\mathbf{6}$ \\
\hline Potassium (K) & 50.96 & 50.59 & 50.38 & 50.21 & 51.22 & 52.03 \\
Chloride (Cl) & 12.20 & 11.18 & 12.83 & 9.61 & 11.90 & 13.45 \\
Calcium (Ca) & 4.92 & 8.10 & 1.48 & 8.56 & 5.90 & 4.67 \\
Phosphor (P) & 1.78 & 1.68 & 1.67 & 1.50 & 1.39 & 1.75 \\
Sulfur (S) & 1.01 & 1.25 & 2.06 & 1.25 & 1.01 & 2.20 \\
Sodium (Na) & 1.37 & 1.27 & 1.08 & 1.67 & 1.77 & 1.22 \\
Cadmium (Cd) & 1.50 & 0.77 & 1.89 & 0.91 & 1.18 & 1.11 \\
Silver (Ag) & 1.33 & 2.01 & 3.20 & 1.31 & 1.52 & - \\
Iron (Fe) & 0.924 & 0.836 & 0.821 & 1.05 & 1.986 & 0.920 \\
Zinc (Zn) & 0.879 & 0.386 & 0.257 & 0.482 & 0.712 & 0.988 \\
Molybdenum (Mo) & 0.712 & - & 0.854 & 0.678 & - & 0.575 \\
Rubidium (Rb) & 0.75 & 0.873 & 0.88 & 0.985 & 1.18 & 0.523 \\
Magnesium (Mg) & 0.410 & 0.425 & 0.290 & 0.315 & 0.392 & 0.431 \\
Silicon (Si) & 0.295 & 0.294 & 0.249 & 0.280 & 0.569 & 0.401 \\
Zirconium (Zr) & 0.239 & 0.209 & 0.125 & 0.219 & 0.167 & 0.249 \\
Argon (Ar) & 0.291 & 0.254 & 0.339 & 0.246 & 0.203 & 0.203 \\
Manganese (Mn) & 0.218 & 0.218 & 0.156 & 0.453 & 0.195 & 0.293 \\
Titanium (Ti) & 0.115 & 0.115 & - & - & 0.089 & 0.504 \\
Barium (Ba) & - & - & 0.80 & - & 0.84 & - \\
Gold (Au) & - & - & 0.74 & - & - & - \\
\hline
\end{tabular}

The XRD patterns of mangosteen pericarp extract are shown in Figure 3. As shown in XRD analysis, mangosteen maturity 1,2 and 3 were amorphous. Although sample 2 was previously seen as crystalline, it was mainly amorphous based on XRD results. Lowest peak in samples 4, 5 and 6 indicates carbon crystal and indicates high xanthone concentration.

$\mathrm{XRF}$ is X-ray method similar to EDX, yet it measures smaller element above 11 atomic number. XRF was performed to confirm results obtained from EDX and XRD analysis. Results of XRF are shown in Table 3. Most of elements were in accordance to previous results analyzed with EDX and there were also several more elements found. Elements $\mathrm{K}, \mathrm{Cl}, \mathrm{Ca}, \mathrm{P}, \mathrm{S}, \mathrm{Na}, \mathrm{Cd}, \mathrm{Fe}, \mathrm{Zn}$, $\mathrm{Rb}, \mathrm{Mg}, \mathrm{Si}, \mathrm{Zr}, \mathrm{Ar}$ and $\mathrm{Mn}$ were detected in all samples. Meanwhile, Ag, Mo and Ti were found in mangosteen pericarp level 1. Similarly, Ag and Ti were detected in mangosteen pericarp level 2; $\mathrm{Ag}, \mathrm{Mo}, \mathrm{Ba}$ and $\mathrm{Au}$ were detected in mangosteen pericarp level 3; $\mathrm{Ag}$ and Mo were detected in mangosteen pericarp level 4; $\mathrm{Ag}$, $\mathrm{Ti}$ and
Ba were detected in mangosteen pericarp level 5; Mo and Ti were detected in mangosteen pericarp level 6.

\section{Discussion}

Dehydration is an efficient alternative for fruit storage in which reduction of water is associated with the decline of chemical and enzymatic reactions that can damage foods. Gentle drying techniques, such as osmodehydration or lyophilisation (freeze drying), have been used as new alternative for the commercialization of tropical fruits to reduce the difficulties for its handling and transport and to acquire added value solids products ${ }^{18}$. In this study, we evaluated microstructure of freeze dried mangosteen pericarp extract at various maturity levels. The structural studies of the fruit powders were done using PSA, SEM, XRD and XRF.

In the present study, particle size of the mangosteen pericarp extract was clearly heterogeneous. Particle of mangosteen pericarp extract at level 5 exhibited the 
smallest size, whereas those at level 3 exhibited the highest size. Particle size distribution does not follow a typical ideal Gauss bell form. Additionally, it seems that the maturity level were not in correlation with the particle size. The particle size may depend on the processing method. This can be also originated from the coagulation of mangosteen particles.

SEM technique is a powerful tool for determining and observing the caking phenomenon on the powder surface. The corresponding EDX spectrums revealing the elemental composition of the samples, exhibited component $\mathrm{C}, \mathrm{O}, \mathrm{Cl}$ and $\mathrm{K}$ in samples. XRF is $\mathrm{X}$-ray method similar to EDX, yet it measures smaller element above 11 atomic numbers. XRF was performed to confirm results obtained from EDX and XRD analysis. Most of elements were in accordance to previous results analyzed with EDX and there were also several more elements found.

Crystallization is essential for the stability of powdered juice and can be investigated through XRD analysis. Amorphous state is indicated with diffused and large peaks in which the molecules are disorderly displayed producing disperse bands, whereas crystalline materials yield sharp and defined peaks since they are presented in a highly ordered state ${ }^{18}$. In this study, mangosteen pericarp level 1, 2 and 3 were amorphous, whilst mangosteen pericarp level 4, 5 and 6 indicates carbon crystal.

This present study, found that in mangosteen pericarp contain elements of $\mathrm{K}, \mathrm{Cl}, \mathrm{Ca}, \mathrm{P}, \mathrm{S}, \mathrm{Na}, \mathrm{Cd}, \mathrm{Fe}, \mathrm{Zn}, \mathrm{Rb}$, $\mathrm{Mg}, \mathrm{Si}, \mathrm{Zr}$, Ar, and Mn. Other studies also mention that in the mangosteen fruit contain $\mathrm{Na}, \mathrm{K}, \mathrm{Mg}, \mathrm{Ca}, \mathrm{Fe}, \mathrm{Mn}$, $\mathrm{Zn}$, and $\mathrm{Cu}^{19}$.

$\mathrm{Fe}, \mathrm{Ca}, \mathrm{Zn}, \mathrm{Cu}$, and $\mathrm{Mn}$ are present in wound fluid, indicating that these elements at the right concentration can be helpful in the wound healing process. Fe concentrations decrease in wound fluids after a day or two days, because most of the Fe has been used in the wound healing process. $\mathrm{Ca}$ is also required in various physiological processes such as blood coagulation, neuromuscular excitability, cellular adhesiveness, maintenance structural integrity and functions of cell membranes ${ }^{20}$.

$\mathrm{Zn}$ has a very important role in wound healing, $\mathrm{Zn}$ capable to enhance platelet activity and aggregation. $\mathrm{Zn}$ deficiency will increase the production of inflammatory cytokines and oxidative stress, obstruct PMN chemotaxis and compromises Neutrophil extracellular traps. Lack of $\mathrm{Zn}$ also disrupt monocytes adhesion. Zn plays a role in increasing $\mathrm{T}$ lymphocyte populations, and granulation tissue formation. $\mathrm{Zn}$ was shown to increase keratinocyte migration and also effective for in vivo angiogenesis ${ }^{21}$.

$\mathrm{Mn}$ is firmly associated with protein synthesis and widely distributed in mammalian tissue ${ }^{20}$.

\section{Conclusion}

Mangosteen pericarp with highest xanthone concentration has crystalline structure and contains iron, calcium, zinc, and manganese, the elements which in the correct concentration can give benefit for wound healing processes. These findings provide information regarding characteristics of mangosteen peel that can be further used for the optimization of xanthone content.

\section{Acknowldegment}

This study was personally funded by authors. We would also like to thank Indonesian Institute of Life Science (LIPI) for its asisstance and supervision.

\section{Conflict of interest}

Authors declare that there is no conflict of interest.

\section{Reference}

1. Suksamrarn S, Suwannapoch N, Ratananukul P, Aroonlerk N, Suksamrarn A. Xanthones from the Green Fruit Hulls of Garcinia mangostana. J Nat Prod. 2002; 65(5):761-3. PMid: 12027762. Crossref.

2. Moongkarndi P, Kosem N, Kaslungka S, Luanratana O, Pongpan N, Neungton N. Anti-proliferation, antioxidation and induction of apoptosis by Garcinia mangostana (mangosteen) on SKBR3 human breast cancer cell line. J Ethnopharmacol. 2004 Jan 1; 90(1):1616. PMid: 14698525 . Crossref.

3. Farnsworth NR, Bunapraphatsara N. Thai medicinal plants recommended for primary health care system. Medicinal Plant Information Center; 1992.

4. Ramasamy S, Mazlan NA, Ramli NA, Rasidi WN, Manickam S. Bioactivity and stability studies of anthocyanin-containing extracts from Garcinia mangostana L. and Etlingera elatior Jack. Sains Malaysiana. 2016; 45(4):559-65. 
5. Tjahjani S, Widowati W, Khiong K, Suhendra A, Tjokropranoto R. Antioxidant properties of Garcinia mangostana L (mangosteen) rind. Procedia Chemist. 2014; 13:198-203. Crossref.

6. Aminah LN, Leong ST, Wong YS, Ong SA, Kairulazam CK. Biodiesel production of Garcinia mangostana Linn seeds by two-phase solvent extraction and alkali-catalyzed transesterification. Int J Chem Eng Appl. 2013; 4(3):92-5. Crossref.

7. Zarena AS, Sankar KU. A study of antioxidant properties from Garcinia mangostana L. pericarp extract. Acta Sci Pol Technol Aliment. 2009; 8(1):23-34.

8. Seesom W, Jaratrungtawee A, Suksamrarn S, Mekseepralard C, Ratananukul P, Sukhumsirichart W. Antileptospiral activity of xanthones from Garcinia mangostana and synergy of gamma-mangostin with penicillin G. BMC Complement Altern Med. 2013; 13(1):182. PMid: 23866810 PMCid: PMC3734031. Crossref.

9. Shan T, Ma Q, Guo K, Liu J, Li W, Wang F, Wu E. Xanthones from mangosteen extracts as natural chemopreventive agents: Potential anticancer drugs. Curr Mol Med. 2011; 11(8):666-77. PMid: 21902651 PMCid: PMC3237908. Crossref.

10. Akao Y, Nakagawa Y, Nozawa Y. Anti-cancer effects of xanthones from pericarps of mangosteen. Int J Mol Sci. 2008; 9(3):355-70. PMid: 19325754 PMCid: PMC2635669. Crossref.

11. Widowati W, Darsono L, Suherman J, Fauziah N, Maesaroh M, Erawijantari PP. Anti-inflammatory effect of mangosteen (Garcinia mangostana L.) peel extract and its compounds in LPS-induced RAW264. 7 cells. Nat Prod Sci. 2016; 22(3):147-53. Crossref.

12. Chaovanalikit A, Mingmuang A, Kitbunluewit T, Choldumrongkool N, Sondee J, Chupratum S. Anthocyanin and total phenolics content of mangosteen and effect of processing on the quality of mangosteen products. Int Food Res J. 2012; 19(3):1047-53.

13. Yunitasari L. Gempur 41 Penyakit dengan Buah Manggis. Yogyakarta: Pustaka Baru Press; 2011.

14. Yatman E. Kulit Buah Manggis Mengandung Xanton yang Berkhasiat Tinggi. Widya. 2012; 29:2-9.

15. Iswari, K., Harnel and Afdi E. Kajian Teknologi Pengolahan Manggis Mendukung Agribisnis Manggis di Sumbar. Research Report of BPTP West Sumatera; 2006.

16. Kurniawati A. Character, xanthone content and antioxidant properties of mangosteen fruit's hull (Garcinia mangostana L.) at Several Fruit Growth Stadia. Indones J Agron. 2017; 39(3):188-92.

17. Palapol Y, Ketsa S, Stevenson D, Cooney JM, Allan AC, Ferguson IB. Color development and quality of mangosteen (Garcinia mangostana L.) fruit during ripening and after harvest. Postharvest Biol Technol. 2009; 51(3):349-53. Crossref.

18. Athmaselvi KA, Kumar C, Balasubramanian M, Roy I. Thermal, structural and physical properties of freeze dried tropical fruit powder. J Food Process. 2014; 2014.

19. Haruenkit R, Poovarodom S, Leontowicz H, Leontowicz M, Sajewicz M, Kowalska T, Delgado-Licon E, RochaGuzmán NE, Gallegos-Infante JA, Trakhtenberg S, Gorinstein S. Comparative study of health properties and nutritional value of durian, mangosteen, and snake fruit: experiments in vitro and in vivo. Journal of Agricultural and Food Chemistry. 2007 Jul 11; 55(14):5842-9.

20. Liyanage JA, Rodrigo I, Wijeratne M. Influence of nutritional factors upon the variation of essential metal concentrations on wound healing. Chemical Speciation \& Bioavailability. 2006 Jan 1; 18(2):57-60.

21. Lin PH, Sermersheim M, Li H, Lee PH, Steinberg SM, Ma J. Zinc in Wound Healing Modulation. Nutrients. 2017 Dec $24 ; 10(1): 16$. 